\title{
CURRENT WORLD \\ ENVIRONMENT \\ Current World Environment \\ Determination of Arsenic Uptake Potential In an Edible Plant Species (Trigonellna Foenum- Granecum) and Assessment of Human Health Risk
}

\author{
K GNAANA SRI KAALIESWARI, DEEP CHAKRABORTY \\ and KRISHNENDU MUKHOPADHYAY*
}

\begin{abstract}
Department of Environmental Health Engineering, Faculty of Public Health, Sri Ramachandra Institute of Higher Education and Research (DU), Chennai, Tamilnadu-600116, India.
\end{abstract}

\begin{abstract}
Arsenic is a carcinogenic and toxic element that possesses a high health risk from its presence in crops, water, and soil. The present study has been conducted by fenugreek (Trigonella foenum-granecum) seeds which is a very common spice used for cooking, especially in India. An equal number of seeds have been germinated in laboratory conditions. Three concentrations e.g. 1,2 , and, $3 \mathrm{mg} / \mathrm{L}$ of arsenite $\left(\mathrm{As}^{+3}\right)$ and arsenate $\left(\mathrm{As}^{+5}\right)$ salt solutions were used throughout the experiments for the treatment of plants. After 10 days of germination, the concentration of the arsenic accumulated into the plant edible parts was estimated and health risk was assessed. Effects of arsenic concentration were observed through estimating the total chlorophyll ( $a, b, c)$, carotenoid content, and taking the fresh weight and dry weight of both the control and treatment plants. The results of the biochemical analysis revealed that chlorophyll and carotenoid contents were decreased than that of control plants. Moreover, fresh weight and dry weight results also showed lower values in treatments than in controls. The bioaccumulation factor results demonstrated that an increased level of soil arsenic doesn't certainly result in high arsenic uptake by the Fenugreek plants. From the concentration estimated in the plant body, the health risk was assessed in adults and children and found that both adults and children having a potential health risk upon consumption of fenugreek. Moreover, Incremental Life Time Cancer Risk was found high which indicates the presence of potential cancer risk. Hence, it is possible to conclude from the present study that fenugreek can bio-accumulate arsenic and it may be used as an indicator plant for arsenic-contaminated areas.
\end{abstract}

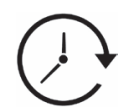

\section{Article History}

Received: 21 July 2020 Accepted: 21 June 2021

\section{Keywords}

Arsenic Toxicity;

Arsenic Indicator Plant;

Fenugreek;

Health Risk Assessmentl; Incremental Life Time

Cancer Risk.

CONTACT Krishnendu Mukhopadhyay krishnendu@ehe.org.in Department of Environmental Health Engineering, Faculty of Public Health, Sri Ramachandra Institute of Higher Education and Research (DU), Chennai, Tamilnadu-600116, India.

\section{(c) (i)}

(c) 2021 The Author(s). Published by Enviro Research Publishers.

This is an Open Access article licensed under a Creative Commons license: Attribution 4.0 International (CC-BY).

Doi: http://dx.doi.org/10.12944/CWE.16.2.16 


\section{Introduction}

Natural and anthropogenic sources are the two major areas from where arsenic (As) may contaminate the normal environment. ${ }^{1}$ Contamination of arsenic can be toxic and fatal if it will enter the food web via water and soil routes. Previous researchers also observed the contamination of groundwater and foods via arsenic in different parts of the world. ${ }^{2,3}$ Contamination of soil by arsenic may result from agricultural activities, various anthropogenic activities, etc. According to Huang et al., (2006) inorganic-As is the most predominant toxic form presents in soil and water. ${ }^{4}$ However, few previous studies reported about As- methylation in the soilpaddy system, where they found that the inorganic form of arsenic may be converted from organic arsenic by microorganisms. ${ }^{5}$ The uptake of arsenic by a plant species depends on many factors like soil properties, the concentration of arsenic present in the soil, and most importantly depends on the plant species itself. ${ }^{6}$ Physical characteristics of plant species is an important aspect which is evident from few previous studies that found the concentration of arsenic was estimated high in root parts followed by leaves, stems, fruits, and seeds. ${ }^{7,8}$ However, Farid et al., (2003) have found aerial parts of leafy vegetables can accumulate high concentration of arsenic than any other plant body parts. ${ }^{9}$ So, it is clear that the bioavailability of arsenic and ability to translocate these two factors were primary which determine the arsenic distribution in the plant body. ${ }^{10}$ Studies on arsenic availability in the plant body are important as they can bioaccumulate in human tissue through the food chain. ${ }^{11}$ The effects of chronic arsenic exposure on humans can cause serious health effects like keratosis, hepatomegaly, pigmentation, diabetes mellitus, cardiovascular and cerebrovascular problems, peripheral neuropathy, kidney, bladder, and skin, etc. ${ }^{12,13}$

Keeping the facts in mind, this study urge to explore the sensitivity and tolerance against the arsenic toxicity in a common plant species, which is widely used as a food ingredient in most of the part of India, and it also will assess the health risk among the population consuming this edible plant species.

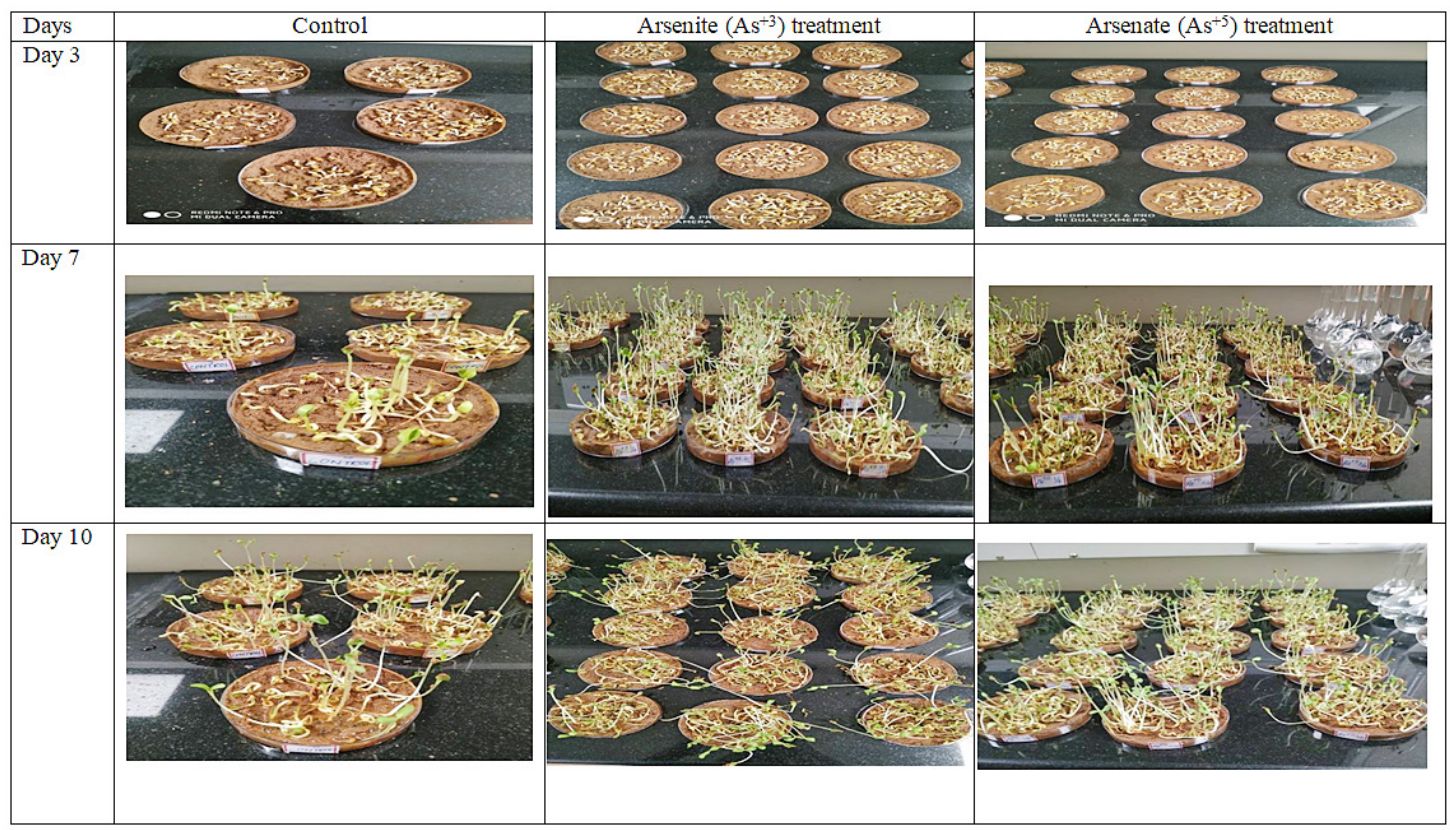

Fig.1: Growth of control and arsenic-treated fenugreek plants in laboratory condition

\section{Materials and Methods \\ Experimental Methodology}

Seeds of fenugreek (Trigonella foenum-graecum) were procured from the grocery stores. Generally, fenugreek leaves were used as vegetables, and seeds were used as common Indian spices. The entire experiment was performed in the laboratory condition. Three different concentrations of sodium arsenite $\left(\mathrm{NaAsO}_{2}\right)$ and sodium arsenate $\left(\mathrm{Na}_{2} \mathrm{HAsO}_{4}\right.$, $7 \mathrm{H}_{2} \mathrm{O}$ ) (dissolved in distilled water only) solutions 
were used for this study. The sterilization process of the experimental seeds was carried out with $1 \%$ sodium hypochlorite $(\mathrm{NaOCl})$ solution for a minute and then washed with double distilled water (DDW). ${ }^{14}$ The process of seeds germination and growth was made in the soil collected from the institute campus using Petri dishes. Petri dishes were covered with lids and were incubated at room temperature $\left(30^{\circ} \mathrm{C}\right)$. Stock solutions of the $\mathrm{As}^{+3}$ and $\mathrm{As}^{+5}$ were prepared by the required amount of arsenic salts in DDW to make $100 \mathrm{ppm}$ solution for each $\mathrm{As}^{+3}$ and $\mathrm{As}^{+5}$. Required dilutions were made to get the working solutions i.e. $1 \mathrm{mg} / \mathrm{L}, 2 \mathrm{mg} / \mathrm{L}$, and $3 \mathrm{mg} / \mathrm{L}$. The experimental study was performed using respective arsenic solutions. The Petri dishes were periodically nourished and moisturized during the entire experimental period with $10 \mathrm{ml}$ of the solution once a day. Control sets of experiments were set up by using only DDW. Three replicates were taken for each treatment and control. Germination and growth of the seeds were observed for 10 days. Estimation of chlorophyll, Carotenoid contents, dry and wet weight was recorded after 10 days of the experiment (Fig. 1).

\section{Determination of Fresh and Dry Weights}

A total of 10 fully grown seedlings with almost uniform size were taken from each dish (both from control and treatments) and were thoroughly washed with DDW to remove the excess soil. Tissue papers were used to soak the excess water. Fresh weights were taken after the seedling was room dried and dry weights were taken after the seedlings were dried at $70^{\circ} \mathrm{C}$ for $48 \mathrm{hr}$ in an oven. ${ }^{14}$

\section{Estimation of Chlorophyll and Carotenoid}

After 10 days of the experiment, fenugreek leaves were taken for the estimation of chlorophyll and carotenoid. Standard methodologies were followed for the estimation of chlorophyll and carotenoid. ${ }^{15}$

\section{Total Arsenic Estimation in Plants}

For estimation of total arsenic, plants were weighed to measure their mass. Two grams of dry plant sample was digested in the tri-acid mixture $\left(\mathrm{HCl}-\mathrm{HNO}_{3}-\mathrm{HClO}_{4}\right)$ until the mixture became a muddy-like texture. The digestion mixture was diluted with DDW to make up the volume to $50 \mathrm{ml}$ and then it was filtered with filter papers. Finally, the filtrate was used for the estimation of arsenic in Atomic Absorption Spectroscopy (Bruker, ARTAX).

\section{Bioaccumulation Factor Calculation}

Bioaccumulation factors (BAF) were calculated by taking the ratio of concentrations found in plants to the soil arsenic concentration Eq. 1.

$$
B A F=\frac{C_{A s-\text { plant }}}{C_{A s-\text { soil }}}
$$

Where $\mathrm{C}_{\text {As-plant }}$ is the concentration of arsenic in the plant body and CAs-Soil is the concentration of arsenic in the soil

\section{Chronic Intake Dose (CDI) Estimation}

$\mathrm{CDI}$ is calculated taking the arsenic concentration found in the fenugreek plant and following the formula Eq. 2:

$$
C D I=\frac{C_{A s} \times C F \times I R_{\text {veg }}}{B W}
$$

Where, $\mathrm{C}_{\mathrm{As}}=$ As-concentration $(\mathrm{mg} / \mathrm{kg}), \mathrm{IR}_{\mathrm{veg}}$ $=$ Intake rate of contaminated plant (mg/day), CF = Conversion factor, BW = Body weight

\section{Risk Assessment}

The mean value of total arsenic concentrations was used in the estimated daily dose (EDD) calculation Eq. $3{ }^{16,17}$

$E D D=\frac{C_{A s} \times I R_{\text {reg }} \times C F \times E F \times E D}{L E \times B W}$

Where, $\mathrm{C}_{\mathrm{As}}=$ As-concentration $(\mathrm{mg} / \mathrm{kg}), \mathrm{IR}_{\mathrm{veg}}=$ Intake rate of contaminated palnt (mg/day), CF = Conversion factor, EF = Exposure factor, ED = Exposure duration (years), LE = Lifetime expectancy, $\mathrm{BW}=$ Body weight

\section{Determination of Hazard Quotient and Hazard Index}

A Hazard Quotient (HQ) is the proportion between potential exposures to the safe level of exposure. Hazard Quotient less than 1predicted to be the safest level. The reference dose (RfD) is the limit above which any chemicals may pose a toxic effect on the health of the human. $\mathrm{HQ}$ was estimated by following Eq. 4. The hazard index (HI) Eq. 5 was calculated as the sum of average $\mathrm{HQ}$ values. ${ }^{18}$

$H Q=\frac{E D D}{R f D}$

$H I=\sum H Q$ 
Incremental Life Time Cancer Risk Assessment For assessment of the incremental lifetime cancer risk (ILTCR), the established formula Eq. 6 was used. ${ }^{18}$ According to USEPA (2010), ILTCR value > $10^{-4}$ indicates high-potential cancer risk, and $<10^{-4}$ indicates probable health risk.

$I L T C R=\frac{C_{A s} \times I R_{v e g} \times C F \times E F \times E D}{L E \times B W} \times C F S$
Where, Where, $\mathrm{C}_{\mathrm{As}}=$ As-concentration $(\mathrm{mg} / \mathrm{kg})$, $\mathrm{IR}_{\mathrm{veg}}=$ Intake rate of contaminated plant (mg/day), $\mathrm{CF}=$ Conversion factor, $\mathrm{EF}=$ Exposure factor, $\mathrm{ED}=$ Exposure duration (years), LE = Lifetime expectancy, $\mathrm{BW}=$ Body weight, $\mathrm{CFS}=$ cancer slope factor (per $\mathrm{mg} / \mathrm{kg} /$ day)

Table 1: Fresh and dry weight of fenugreek plants

\begin{tabular}{cccc}
\hline & & Fresh weight $(\mathbf{g})$ & Dry weight $(\mathbf{g})$ \\
\hline & Control/ Treatments & $5.551 \pm 0.124$ & $0.689 \pm 0.177$ \\
Arsenite $(\mathrm{mg} / \mathrm{L})\left(\mathrm{As}^{+3}\right)$ & 1 & $5.127 \pm 0.826$ & $0.686 \pm 0.089$ \\
& 2 & $5.106 \pm 0.867$ & $0.652 \pm 0.171$ \\
Arsenate $(\mathrm{mg} / \mathrm{L})\left(\mathrm{As}^{+5}\right)$ & 3 & $4.899 \pm 0.700$ & $0.612 \pm 0.030$ \\
& 1 & $4.481 \pm 0.339$ & $0.655 \pm 0.069$ \\
& 2 & $5.030 \pm 0.541$ & $0.630 \pm 0.047$ \\
& 3 & $4.558 \pm 0.088$ & $0.497 \pm 0.039$ \\
\hline
\end{tabular}

Table 2: Chlorophyll and Carotenoid content of the control, $\mathrm{As}^{+3}$, and $\mathrm{As}^{+5}$ treated fenugreek plants

\begin{tabular}{|c|c|c|c|c|c|}
\hline & & $\begin{array}{l}\text { Chl a }(\mathrm{mg} / \mathrm{g} \\
\text { Mean } \pm \text { SD) }\end{array}$ & $\begin{array}{l}\text { Chl b }(\mathrm{mg} / \mathrm{g} \\
\text { Mean } \pm \text { SD) }\end{array}$ & $\begin{array}{l}\text { Total Chl }(\mathrm{mg} / \mathrm{g} \\
\text { Mean } \pm \text { SD) }\end{array}$ & $\begin{array}{c}\text { Carotenoid }(\mathrm{mg} / \mathrm{g} \\
\text { Mean } \pm \text { SD) }\end{array}$ \\
\hline \multicolumn{2}{|c|}{ Control/Treatments } & $0.559 \pm 0.024$ & $0.712 \pm 0.467$ & $1.042 \pm 0.184$ & $0.226 \pm 0.022$ \\
\hline Arsenite (mg/L) & 1 & $0.535 \pm 0.125$ & $0.17 \pm 0.141$ & $0.695 \pm 0.318$ & $0.128 \pm 0.080$ \\
\hline \multirow[t]{2}{*}{$\left(\mathrm{As}^{+3}\right)$} & 2 & $0.519 \pm 0.147$ & $0.224 \pm 0.067$ & $0.792 \pm 0.224$ & $0.159 \pm 0.065$ \\
\hline & 3 & $0.413 \pm 0.093$ & $0.163 \pm 0.028$ & $0.609 \pm 0.124$ & $0.109 \pm 0.030$ \\
\hline Arsenate (mg/L) & 1 & $0.422 \pm 0.135$ & $0.175 \pm 0.058$ & $0.633 \pm 0.202$ & $0.091 \pm 0.026$ \\
\hline \multirow[t]{2}{*}{$\left(\mathrm{As}^{+5}\right)$} & 2 & $0.612 \pm 0.088$ & $0.230 \pm 0.032$ & $0.881 \pm 0.122$ & $0.178 \pm 0.032$ \\
\hline & 3 & $0.532 \pm 0.064$ & $0.2 \pm 0.038$ & $0.768 \pm 0.109$ & $0.145 \pm 0.035$ \\
\hline
\end{tabular}

Table 3: Concentration of Arsenic in soils and in fenugreek plants and respective bioaccumulation factors

\begin{tabular}{ccccc}
\hline & Treatments & Soil $\left(\mathbf{m g ~ k g}^{-1}\right)$ & Plant $\left(\mathbf{m g ~ k g} \mathbf{~}^{-1}\right)$ & BAF \\
\hline Arsenite $(\mathrm{mg} / \mathrm{L})\left(\mathrm{As}^{+3}\right)$ & 1 & $0.238 \pm 0.002$ & $0.155 \pm 0.002$ & 0.651 \\
& 2 & $0.236 \pm 0.001$ & $0.243 \pm 0.007$ & 1.028 \\
& 3 & $0.259 \pm 0.001$ & $0.223 \pm 0.001$ & 0.857 \\
Arsenate $(\mathrm{mg} / \mathrm{L})\left(\mathrm{As}^{+5}\right)$ & 1 & $0.536 \pm 0.004$ & $0.159 \pm 0.002$ & 0.297 \\
& 2 & $0.159 \pm 0.001$ & $0.116 \pm 0.003$ & 0.724 \\
& 3 & $0.133 \pm 0.004$ & $0.209 \pm 0.002$ & 1.573 \\
\hline
\end{tabular}

BAF: Bioaccumulation factor 


\section{Results and Discussion}

Table 1 represents the fresh and dry weight of the control and treatment plant samples. After the experimental period was over, it was observed that control plants showed higher weight than that of treatments. Among all the treatments, $3 \mathrm{mg} / \mathrm{L}$ treatments in both $\mathrm{As}^{+3}$ and $\mathrm{As}^{+5}$ showed the lowest wet weight $(4.899 \pm 0.700 \mathrm{~g}$; and $4.558 \pm 0.088 \mathrm{~g})$ as well as dry weight $(0.612 \pm 0.030 \mathrm{~g}$; and $0.497 \pm$ $0.039 \mathrm{~g}$ ), respectively. Chlorophyll and carotenoid contents were estimated in both the control and treatment groups. It was observed from table 2 that chlorophyll and carotenoid contents were decreased irrespective of treatments than that of the control group. However, results found that with the increasing concentrations of arsenic the chlorophyll and carotenoid contents were decreased in both the treatment groups. Results revealed that in $3 \mathrm{mg} / \mathrm{L}$ treatment of $\mathrm{As}^{+3}$, the chlorophyll a, chlorophyll b, total chlorophyll, and carotenoid were found $0.413 \pm$ $0.093 \mathrm{mg} / \mathrm{g}, 0.163 \pm 0.028 \mathrm{mg} / \mathrm{g}, 0.609 \pm 0.124 \mathrm{mg} / \mathrm{g}$, and $0.109 \pm 0.030 \mathrm{mg} / \mathrm{g}$, respectively. This decrease in concentration indicates that the chlorophyll synthesis system and chlorophyllase activities might be affected by the exposure to a high level of toxic metal concentrations. ${ }^{5}$ The same trends have been observed in $3 \mathrm{mg} / \mathrm{L}$ of $\mathrm{As}^{+5}$ treatment $(0.532$ $\pm 0.064,0.2 \pm 0.038,0.768 \pm 0.109$, and $0.145 \pm$ 0.035 in case of chlorophyll a, chlorophyll b, total chlorophyll and carotenoid, respectively. Although there was no previous report on the effect of arsenic concentration on the chlorophyll content in the fenugreek plant, however, Miteva and Merakchiyska (2002) reported that arsenic may put an effect on the photosynthetic process in bean plants. ${ }^{19}$ The uptake potential of arsenic by a crop depends on the concentration of arsenic in water, soil and it also depends on soil and crop's physiological properties. ${ }^{3}$ The concentration of soil arsenic and in the plant shoot portion in each treatment were represented in Table 3. Probably these higher arsenic contents might have resulted from the direct absorption of arsenic from the soil environment. Similar results have been observed by previous researchers, who reported that the concentrations of arsenic in the plant's body might increase more or less linearly with the total concentration of arsenic available in the

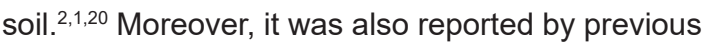
researchers that the high concentration of arsenic in the soil might result in a high concentration of arsenic in the plant body. ${ }^{4}$
On the other hand, soil arsenic concentration was also estimated to find out the ability of arsenic accumulation by fenugreek plants. However, bioaccumulation factor (BAF) analysis results showed that an independent relationship with soil arsenic concentration (Table 3 ). The highest bioaccumulation factor was found in $2 \mathrm{mg} / \mathrm{L} \mathrm{As}^{+3}$ treatments $(1.028)$ and $3 \mathrm{mg} / \mathrm{L} \mathrm{As}^{+5}$ treatments (1.573). The study results showed that the increased concentration of soil Arsenic may not certainly represent higher arsenic accumulation by the fenugreek plants. This result may differ in different plants due to the difference in physiological characteristics. Moreover, our present study results were very similar to the study reported by Mandal and Suzuki (2002). ${ }^{21}$ On the other hand, Das et al., (2004) was also observed that the concentration of arsenic in potato, vegetable leaves, rice, spinach, the gourd was in the range between 0.02 to $3.99 \mathrm{mg}$ $\mathrm{kg}^{-1}$ while estimated from an arsenic-contaminated field. ${ }^{22}$ Pendergrass and Butcher (2006) were also have found the bioaccumulation of arsenic in the range of 1.5 to $178 \mathrm{mg} \mathrm{kg}^{-1}$ in plants. ${ }^{23}$ Correlation study between soil and plant arsenic concentration with pigment contents were represented in Table 4. The study result showed that soil and plant arsenic concentration had a negative correlation with all estimated pigment contents i.e., chlorophyll a: -0.699 ; chlorophyll b: -0.474 ; total chlorophyll: -0.638; carotenoid: -0.783 and chlorophyll a: -0.445 ; chlorophyll b: -0.081 ; total chlorophyll: -0.277 ; carotenoid: -0.124 . It was clear from the study results that pigments contents were affected by the arsenic concentrations which invariably means that fenugreek is not an arsenic resistant species but it can be used as an indicator plant variety in arsenic contaminated areas. It is important to measure the level of toxicity by quantifying the arsenic exposure pathways to determine the human health risk. To estimate the potential human health risk associated with fenugreek consumption, chronic daily intake (CDI) was estimated. Table 5 summarized the CDI and $\mathrm{HQ}$ for adults and children upon consumption. The results revealed that the CDI values for adults and children were relatively high in both arsenic $\left(\mathrm{As}^{+3}\right.$ and $\left.\mathrm{As}^{+5}\right)$ concentrations. However, all CDI values are $<1$. $H Q$ is used often to evaluate a possible non-cancerous health risk from toxic pollutants. It was observed that most of the $\mathrm{HQ}$ values for children were high than the adults irrespective of treatments. It might be due to higher 
intake rates and lower body weights for the children. Some previous community-level studies reported that children and teenagers might pose a high risk due to the consumption of arsenic-contaminated vegetables. ${ }^{24}$ The hazard index $(\mathrm{HI})$ for adults and child considering exposure to all As+3 treatments were estimated as 2.85E-01 and 4.16E-01, respectively. The same for As+5 were 2.23E-01, and 3.25E-01 for adult and child, respectively. Individual $\mathrm{HQs}$ and cumulative $\mathrm{HI}$ for both adults and children were found to be less than unity in the observed study. Hence, exposure to As+3 and As+5 due to consumption of fenugreek should not cause any non-cancer health hazard in either adults or children.

Table 4: Correlation between plant Chlorophyll and Carotenoid contents, Plant and Soil arsenic concentration

\begin{tabular}{lccccc}
\hline & Chl a & Chl b & Total Chl & Carotenoid & Soil As \\
\hline Chl b & 0.749 & & & & \\
Total Chl & $0.926^{* *}$ & $0.940^{* *}$ & & & \\
Carotenoid & $0.906^{*}$ & $0.894^{*}$ & $.963^{* *}$ & & \\
Soil As & -0.699 & -0.474 & -0.638 & -0.783 & \\
Plant As & -0.445 & -0.081 & -0.277 & -0.124 & -0.116 \\
\hline
\end{tabular}

** Significant at the 0.01 level (2-tailed)

* Significant at the 0.05 level (2-tailed)

Table 5: Calculated CDI and $\mathrm{HQ}$ values from the concentration estimated from fenugreek in different treatments

\begin{tabular}{lccccc}
\hline & $\begin{array}{c}\text { Concentration/ } \\
\text { Treatments }\end{array}$ & CDI (adult) & CDI (children) & HQ (adult) & HQ (children) \\
\hline Arsenite $(\mathrm{mg} / \mathrm{L})\left(\mathrm{As}^{+3}\right)$ & 1 & $2.26 \mathrm{E}-02$ & $3.30 \mathrm{E}-02$ & $7.13 \mathrm{E}-02$ & $1.04 \mathrm{E}-01$ \\
& 2 & $3.54 \mathrm{E}-02$ & $5.16 \mathrm{E}-02$ & $1.12 \mathrm{E}-01$ & $1.63 \mathrm{E}-01$ \\
$\mathrm{HI}$ & 3 & $3.25 \mathrm{E}-02$ & $4.73 \mathrm{E}-02$ & $1.02 \mathrm{E}-01$ & $1.49 \mathrm{E}-01$ \\
Arsenate $(\mathrm{mg} / \mathrm{L})\left(\mathrm{As}^{+5}\right)$ & 1 & & & $2.85 \mathrm{E}-01$ & $4.16 \mathrm{E}-01$ \\
& 2 & $2.32 \mathrm{E}-02$ & $3.39 \mathrm{E}-02$ & $7.32 \mathrm{E}-02$ & $1.07 \mathrm{E}-01$ \\
$\mathrm{HI}$ & 3 & $1.69 \mathrm{E}-02$ & $2.46 \mathrm{E}-02$ & $5.32 \mathrm{E}-02$ & $7.76 \mathrm{E}-02$ \\
& & $3.06 \mathrm{E}-02$ & $4.46 \mathrm{E}-02$ & $9.64 \mathrm{E}-02$ & $1.41 \mathrm{E}-01$ \\
& & & & $2.23 \mathrm{E}-01$ & $3.25 \mathrm{E}-01$ \\
\hline
\end{tabular}

Table 6: Calculated EDD and ILTCR values from the concentration estimated from fenugreek in different treatments

\begin{tabular}{lccccc}
\hline \multicolumn{7}{c}{$\begin{array}{c}\text { Concentration/ } \\
\text { Treatments }\end{array}$} & EDD (adult) & EDD children) & ILTCR (adult) ILTCR (children) \\
\hline Arsenite $(\mathrm{mg} / \mathrm{L})\left(\mathrm{As}^{+3}\right)$ & 1 & $2.26 \mathrm{E}-02$ & $3.30 \mathrm{E}-02$ & $7.1 \mathrm{~S} 3 \mathrm{E}-02$ & $1.04 \mathrm{E}-01$ \\
& 2 & $3.54 \mathrm{E}-02$ & $5.16 \mathrm{E}-02$ & $1.12 \mathrm{E}-01$ & $1.63 \mathrm{E}-01$ \\
& 3 & $3.25 \mathrm{E}-02$ & $4.73 \mathrm{E}-02$ & $1.02 \mathrm{E}-01$ & $1.49 \mathrm{E}-01$ \\
Arsenate $(\mathrm{mg} / \mathrm{L})\left(\mathrm{As}^{+5}\right)$ & 1 & $2.32 \mathrm{E}-02$ & $3.39 \mathrm{E}-02$ & $7.32 \mathrm{E}-02$ & $1.07 \mathrm{E}-01$ \\
& 2 & $1.69 \mathrm{E}-02$ & $2.46 \mathrm{E}-02$ & $5.32 \mathrm{E}-02$ & $7.76 \mathrm{E}-02$ \\
& 3 & $3.06 \mathrm{E}-02$ & $4.46 \mathrm{E}-02$ & $9.64 \mathrm{E}-02$ & $1.41 \mathrm{E}-01$ \\
\hline
\end{tabular}


EDD and ILTCR were estimated to determine the cancer risks associated with arsenic-contaminated fenugreek shoot ingestion by the common people (Table 6). The EDD values were found greater than the acceptable limits for daily exposure of total arsenic. The study results revealed that the potential cancer risk was found from the estimation of ILTCR for both adults and children as the values found to be $>10-4$.

\section{Conclusion}

Findings from this research will add some new information on arsenic toxicity assessment in an edible vegetable plant. The present study showed that the pigment content decreased in fenugreek with the increasing concentration of both $\mathrm{As}^{+3}$ and $\mathrm{As}^{+5}$ treatments. This study also concluded that a high concentration of soil arsenic content does not necessarily mean a higher accumulation rate in plant body parts and it may depend on the plant physiological properties. Results also indicated that fenugreek grown in arsenic-contaminated areas may pose a potential health risk upon consumption as a vegetable by adults and children. This experimental study results concluded that fenugreek may be used as an indicator plant species in arseniccontaminated areas which will be helpful for easy health risk assessment.

\section{Acknowledgment}

The authors want to thank the Department of Environmental Health Engineering, Faculty of Public Health, Sri Ramachandra Institute of Higher Education and Research (DU), Chennai for permitting to conduct the study.

\section{Funding}

The authors sincerely thank the "Chancellor's Summer Fellowships for UG of Sri Ramachandra Institute of Higher Education and Research (DU) 2019" for funding the research study.

\section{Conflict of Interest}

The authors do not have any conflict of interest.

\section{References}

1. Sharifi, R., Moore. F., Keshavarzi. B. (2014). Potential health risks of arsenic, antimony, and mercury in the Takab geothermal field, NW Iran. Int J Environ Stud, 71, 372-390.

2. Karimi, N., Ghaderian, S. M., Maroofi, H., Schat, H. (2010). Analysis of arsenic in soil and vegetation of a contaminated area in Zarshuran, Iran. Int J Phytoremediation, 12, 159-173.

3. Norra, S., Berner, Z.A., Agarwala, P., Wagner, F., Chandrasekharam, D., Stu, "ben D. (2005). Impact of irrigation with arsenic rich groundwater on soil and crops: a geochemical case study in West Bengal delta plain, India. Applied Geochem, 20, 1890-1906.

4. Huang, R.Q., Gao, S.F., Wang, W.L., Staunton, S., Wang, G. (2006). Soil arsenic availability and the transfer of soil arsenic to crops in suburban areas in Fujian Province, southeast China. Sci Total Environ, 368, 531-541.

5. Van Assche., F.V., Clijsters, H. (1990).Effects of metals on enzyme activity in plants. Plant Cell Environ, 13, 95-206.
6. Alam, M.G.M., Snow, E.T., Tanaka, A. (2003). Arsenic and heavy metal contamination of vegetables grown in Samta village, Bangladesh. Sci Total Environ, 308, 83-96.

7. Carbonell-Barrachina, A.A., Burló-Carbonell, F., Mataix-Beneyto, J. (1992). Arsenic uptake, distribution, and accumulation in bean plants: Effect of Arsenite and salinity on plant growth and yield. J. Plant Nutr, 20(10), 1419-1430.

8. Carbonell-Barrachina, A. A., Burlo, J.F., Burgos-Hernkdez, A., Lopez, E., Mataix, J. (1995). The influence of arsenite concentration on arsenic accumulation in tomato and bean plants. Sci Hortic, 71(3-4), 167-176.

9. Farid, A.T.M., Roy, K.C., Hossain, K.M., Sen, R. (2003). A study of arsenic contaminated irrigation water and its carried over effect on vegetable. Fate of arsenic in the environment. Dhaka: Bangladesh University of Engineering and Technology, 113-121.

10. Kazia, T.G., Araina, M.B., Baig, J.A., Jamali, M.K., Afridi, H.I., Jalbani, N. et al. (2009). The correlation of arsenic levels in drinking water with the biological samples of skin disorders. 
Sci Total Environ, 407, 1019-1026.

11. Anawar, H.M., Akai, J., Komaki, K., Terao, H., Yoshioka, T., Ishizuka, T., Kato, K. (2003). Geochemical occurrence of arsenic in groundwater of Bangladesh: sources and mobilization processes. J Geochem Explor, 77(2), 109-131.

12. IARC-International Agency for Research on Cancer. (2001). Arsenic in drinking-water, in: IARC monographs on the evaluation of carcinogenic risks to humans, some drinkingwater disinfectants and contaminants, including Arsenic, World Health OrganizationInternational Agency for Research on Cancer, Lyon. 84, 39-270.

13. EPA-Environmental Protection Agency. (2012). http://www.epa.gov/iris/subst/0278. html. Accessed 14 Nov 2012.

14. Mondal, N.K. (2017). Effect of fluoride on photosynthesis, growth and accumulation of four widely cultivated rice (Oryzasativa L.) varieties in India. Ecotoxicol Environ Safety, 144, 36-44.

15. Chakraborty, D., Dey, U., Medda, S., Datta, J.K., Roy, T., Mondal, N.K. (2014). Effects of ultraviolet radiation on pigmentation and malondialdehyde content of three aquatic macrophytes. Commu Plant Sci, 4(1-2), 35-41.

16. USEPA (U.S. Environmental Protection Agency). (2011). Exposure factors handbook 2011 edition (final).US Environmental Protection Agency, Washington, DC, EPA/600/R09/052F. http://cfpub.epa.gov/ ncea/risk/recordisplay. cfm?deid=236252. Accessed 20 Sep 2012.

17. EA Engineering, Science, and Technology, Inc. (2010). Remedial investigation report Iron King Mine Humboldt Smelter Superfund Site
Dewey Humboldt, Yavapai County,Arizona. http://yosemite.epa.gov/r9/sfund/r9sfdocw. nsf/3dc283e6c5d6056f88257426007417a2/ 9ff58681f889089c882576fd0075ea2f!Open Document Accessed 19 June 2012.

18. USEPA (U.S. Environmental Protection Agency). (1998). Integrated risk information system: arsenic, inorganic, CASRN 7440-382 Washington, DC.

19. Miteva, E., Merakchiyska, M. (2002). Response of chloroplasts and photosynthetic mechanism of bean plants to excess arsenic in soil. Bulg J Agric Sci, 8, 151-156.

20. Li, Y., Wang, H., Wang, H., Yin, F., Yang, X., Hu, Y. (2014). Heavy metal pollution in vegetables grown in the vicinity of a multi-metal mining area in Gejiu, China: total concentrations, speciation analysis, and health risk. Environ Sci Pollu Res, 21, 12569-12582.

21. Mandal, B.K., Suzuki, K.T. (2002). Arsenic round the world: a review. Talanta, 58,201-235.

22. Das, H.K., Mitra, A.K., Sengupta, P.K., Hossain, A., Islam, F., Rabbani, G.H. (2004). Arsenic concentrations in rice, vegetables, and fish in Bangladesh: a preliminary study. Environ Int, 30, 383-387.

23. Pendergrass, A., Butcher, D.J. (2006). Uptake of lead and arsenic in food plants grown in contaminated soil from Barber Orchard, NC. Microchem, J 83(1), 14-16.

24. Jiang, Y., Zeng, X., Fan, X., Chao, S., Zhu, M., Cao, H. (2015). Levels of arsenic pollution in daily foodstuffs and soils and its associated human health risk in a town in Jiangsu Province, China. Ecotoxicol Environ Safety, 122, 198-204. 